\title{
THE JENSEN INEQUALITY IN AN EXTERNAL FORMULA
}

\author{
Jun-ICHi FujII, Josip PEČARIĆ AND YUKi SEO
}

Abstract. The classical Jensen inequality is expressed by internally dividing points and so is non-commutative Jensen inequalities. In this paper, considering that it is expressed by externally dividing points, we shall discuss two non-commutative Jensen inequalities and their reverse, that is, one is a vector state version and the other is a Davis-Choi-Jensen type version.

Mathematics subject classification (2010): 47A63. inequality.

Keywords and phrases: Jensen inequality, Operator concave, Davis-Choi-Jensen inequality, reverse

\section{REFERENCES}

[1] M. D. ChoI, A Schwarz inequality for positive linear maps on $C^{*}$-algebras, Illinois J. Math. 18 (1974), 565-574.

[2] C. DAVIS, A Schwartz inequality for convex operator functions, Proc. Amer. Math. Soc. 8 (1957), $42-44$.

[3] J. I. FuJII, An external version of the Jensen operator inequality, Sci. Math. Japon. Online, e-2011, $59-62$.

[4] T. Furuta, J. Mićić Hot, J. Pečarić And Y. Seo, Mond-Pečarić Method in Operator Inequalities, Monographs in Inequalities 1, Element, Zagreb, 2005.

[5] F. HANSEN, J. PEČARIĆ AND I. PERIĆ, Jensen's operator inequality and its converses, Math. Scand. 100 (2007), 61-73.

[6] F. HANSEn AND G. K. Pedersen, Jensen's inequality for operators and Lowner's theorem, Math. Ann. 258 (1982), 229-241.

[7] F. Hansen And G. K. Pedersen, Jensen's operator inequality, Bull. London Math. Soc. 35 (2003), 553-564.

[8] B. Mond And J. PeČArIĆ, Convex inequalities in Hilbert space, Houston J. Math. 19 (1993), 405420.

[9] B. Mond And J. PeČARIĆ, Remarks on Jensen's inequality for operator convex functions, Ann. Univ. Mariae Curie-Sklodowska Sec. A. 47 (1993), 96-103.

[10] J. PeČarić, F. Proschan and Y. L. Tong, Convex functions, Partial Orderings, and Statistical Applications, Academic Press, Inc. 1992.

[11] W. F. Stinespring, Positive functions on $C^{*}$-algebras, Proc. Amer. Math. Soc. 6 (1955), 211-216. 